\title{
Living Together as Neighbours: Rethinking the Reasonableness Standard in Nuisance Law Under the Constitution
}

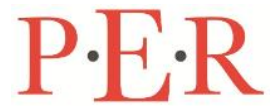

Pioneer in peer-reviewed, open access online law publications

\section{Authors}

Tina Kotzé

Zsa- Zsa Boggenpoel

\section{Affiliation}

Stellenbosch University, South Africa

\section{Email}

\section{tinakotze@sun.ac.za} zsazsa@sun.ac.za

Date Submission

18 May 2021

\section{Date Revised}

23 September 2021

\section{Date Accepted}

\section{September 2021}

Date published

18 October 2021

Editor Dr A Gildenhuys

How to cite this article

Kotzé T and Boggenpoel Z "Living Together as Neighbours:

Rethinking the Reasonableness Standard in Nuisance Law Under the Constitution" PER / PELJ 2021(24) - DOI http://dx.doi.org/10.17159/1727$3781 / 2021 / \mathrm{v} 24$ i0a11169

\section{Copyright}

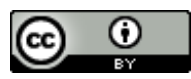

DOI

http://dx.doi.org/10.17159/1727$3781 / 2021 / \mathrm{v} 24$ i0a11169

\begin{abstract}
The Covid-19 pandemic, with its concomitant "stay at home" catchphrase, has certainly made living together as neighbours in a constitutional dispensation more tangible. Conflicts between neighbours will inevitably increase, especially in a time when citizens from different social, cultural, customary or religious backgrounds and with different rights and interests are restricted to the boundaries of their properties as a result of the Covid19 pandemic. The pandemic has provided us with the impetus to reflect upon the notion of "reasonableness" in neighbour law, particularly nuisance law in the narrow sense. In this context the role of neighbour law is ordinarily to regulate the relationship between neighbours. Therefore, neighbour law is crucial in that it resolves conflicts that arise between neighbours due to their everyday use of their properties.
\end{abstract}

Whether the nuisance is objectively reasonable or goes beyond that which can be reasonably tolerable under the circumstances requires weighing up various factors dependant on the prevailing circumstances, rights, interests, values and obligations of the neighbours and the community. In the constitutional dispensation, based on the values of human dignity, equality, and freedom, this may inadvertently require courts to balance out and reconcile often opposing constitutional rights. To this end the underlying principle of nuisance law encapsulated in the phrases "give and take" and "live and let live" arguably already encapsulates the notion of balancing respective rights (constitutional or otherwise) and interests given the context of each case.

However, courts do not always correctly apply the reasonableness test in a principled and coherent fashion, as illustrated in Ellaurie $v$ Madrasah Taleemuddeen Islamic Institute 20212 SA 163 (KZD). This may lead to the conclusion that constitutional rights are ignored when the reasonableness test for nuisance law is applied. It is necessary to reconceptualise the reasonableness test in order to ensure that the common law is infused with constitutional values. There are numerous ways in which the ideals and values of the Constitution of the Republic of South Africa, 1996 (and even specific constitutional rights other than property rights) could be advanced if courts were more willing (not being held back by conservatism) and able (equipped with the necessary vocabulary) to apply the common law in line with the Constitution. It is pivotal that courts apply the reasonableness test correctly, considering all the relevant circumstances of the case, including the broader constitutional values and ideals such as ubuntu. It is arguable that if this were done, nuisance law would have a greater potential to incorporate a wider range of rights, interests and values so that the outcomes would be fairer and more equitable, which is, after all, the goal of the reasonableness standard in neighbour law.

\section{Keywords}

Neighbour law; nuisance law; reasonableness; Covid-19 pandemic, ubuntu. 


\section{Introduction}

The year 2020 will arguably be considered the year in which society as a whole was forced to make major adjustments as a result of the Covid-19 pandemic. ${ }^{1}$ The global pandemic introduced a "new normal" and with it, a myriad of ways in which social distancing, safety and health protocols and the wearing of masks have become commonplace in our daily lives. In addition, the Covid-19 pandemic may also have forced us as a society to rethink how we work from home. In this regard, people have been encouraged to work from home and children could even opt for homeschooling to complete the rest of the academic year. This implies more time at home, which in turn potentially implies more opportunity for neighbour law, particularly nuisance law disputes. This is in addition to the fact that societies are already becoming more diverse, and people are living in closer proximity to one another. ${ }^{2}$ Conflicts will inevitably arise amongst neighbouring owners, especially in urban areas, ${ }^{3}$ and even more so at a time where citizens are restricted to the boundaries of their properties as a result of the Covid-19 pandemic.

Tina Kotzé. BA (Law) LLB LLM (cum laude) LLD (US). Junior lecturer in the Department of Private Law and post-doctoral research fellow at the South African Research Chair in Property Law (SARCPL), hosted by Stellenbosch University, South Africa, funded by the Department of Science and Technology and administered by the National Research Foundation (NRF). E-mail: tinakotze@sun.ac.za. ORCID ID: https://orcid.org/0000-0002-1626-4495. The financial assistance of the NRF is hereby acknowledged. As co-authors we are also incredibly grateful for the valuable inputs of the anonymous reviewers.

** Zsa-Zsa Boggenpoel. B Comm (Law) LLB LLD (US). Professor in Public Law, Stellenbosch University, South Africa and South African Research Chair in Property Law (SARCPL), hosted by Stellenbosch University, funded by the Department of Science and Technology and administered by the National Research Foundation (NRF). E-mail: zsazsa@sun.ac.za. ORCID ID: https://orcid.org/0000-0001-78163393.

1 President Cyril Ramaphosa declared a National State of Disaster on 15 March 2020 due to the outbreak of a pandemic caused by the Covid-19 virus. Opting for the recognition of the Covid-19 pandemic as a state of disaster meant that the Minister of Cooperative Governance and Traditional Affairs, Dr Nkosazana Dhlamini Zuma, could make regulations in terms of the Disaster Management Act 57 of 2002 to manage the pandemic. Subsequently the South African's government's response was to issue numerous regulations and guidelines (or directions) at five different stages or levels, all impacting on various rights that citizens were ordinarily used to, including property rights. For a full overview of the list of regulations and guidelines issued by the South African government, see South African Government 2021 https://www.gov.za/covid-19/resources/regulations-and-guidelines-coronaviruscovid-19.

2 Mostert "Nuisance" 258.

3 Van der Walt Law of Neighbours 240. 
There are still many neighbourhoods in South Africa where the lack of diversity reminds us of the discriminatory apartheid land laws that legalised the geographical separation of different race groups. ${ }^{4}$ Nonetheless, there are an increasing number of neighbourhoods where communities are integrated, and this has "brought with it the kind of diversity that is envisaged and fostered by the Constitution". ${ }^{5}$ Where greater integration occurs, some people may perceive social, cultural, customary and even religious activities that are different from what they are accustomed to as disruptive, or describe them as a "nuisance". ${ }^{6}$ In the context of nuisance law in the narrow sense, these activities now presumably fall outside the scope of what has ordinarily been considered as a reasonable infringement of the neighbour's property rights $^{7}$ in property law, simply because they differ from those familiar and ordinarily tolerated activities in a particular area. ${ }^{8}$ In this respect, Muller $^{9}$ explains that a landowner or occupier may not use his or her property in a way that causes unreasonable discomfort or harm to his/her neighbours. In essence, neighbour law regulates disputes arising from people's living in close proximity to one another on the basis of two main principles which underpin the so-called reasonableness standard in South African law. First, there is a reciprocal obligation on neighbouring landowners and users to tolerate a reasonable level of interference emanating from the reasonable (and lawful) use of neighbouring properties.

$4 \quad$ Numerous pieces of legislation had this effect. These include the Natives Land Act 27 of 1913 subsequently renamed the Black Land Act 27 of 1913; the Native Trust and Land Act 18 of 1936 subsequently renamed the Development Trust and Land Act 18 of 1936; the Group Areas Act 41 of 1950; and the Group Areas Act 36 of 1966. Together, the Natives Land Act and the Native Trust and Land Act can be regarded as forming significant cornerstones of apartheid, which largely underpins the spatial injustice that exists in the context of land today.

$5 \quad$ Mostert "Nuisance" 279.

6 Nuisances may arise as a result of repeated or ongoing emissions of gasses, unpleasant smells dust, water pollution, the seepage of oil and petrol, flies, leaves, vibrations and noise. For a definition of "nuisance" in the narrow sense, see Milton 1969 Acta Juridica 137; Van der Merwe "Neighbour Law" 759; Muller et al Silberberg and Schoeman's Law of Property 125. See further Van der Merwe Oorlas in die SuidAfrikaanse Reg 187; Church and Church "Nuisance" 115-145 para 163. However, see Prinsloo v Shaw 1938 AD 570, where a final interdict was awarded because the times and manner of the religious services amounted to a noise nuisance - not because the religious services were perceived as "unusual" for the area.

7 Reasonable use of a property is contextual and may be determined with reference to the purpose or zoning (residential, agricultural, industrial, commercial) of the property. See for example Holland v Scott 18822 EDC 307 324-325, where the court decided that the nuisance caused by the commercial (or industrial use) of property in a residential area could be construed as a nuisance. See further Graham $v$ Dittmann and Son 1917 TPD 288 291-292; Malherbe v Ceres Municipality 19514 SA 510 (A). Also see Muller General principles of the South African Property Law 97-98.

$8 \quad$ Mostert "Nuisance" 279.

$9 \quad$ Muller General Principles of the South African Property Law 97-98. 
Second, such an interference may become unlawful and therefore actionable, if it "exceeds the level of what neighbours could reasonably be expected (or are required by statute) to tolerate."10

From a normative perspective, considerations of the inherent social, cultural, customary and/or religious attributes of the area in which the alleged nuisance occurs should arguably be taken into account when determining whether the use of any property and the alleged infringement is reasonable or not. Other considerations such as the locality (zoning) of the property, the effects of the nuisance (the gravity of the harm), the personality of the plaintiff, whether the landowner, community and general public benefit from the activity, and "the prevailing view of the community, and the constitutional goals of creating a non-discriminatory society supporting dignity, equality and freedom"11 should also be taken into account should future nuisance cases arise. Whether these considerations are in fact part and parcel of the reasonableness standard and facilitate a deeper understanding of the diversity of society in South Africa is questionable. $^{12}$

In this context Van der Walt ${ }^{13}$ explores the notion of living together as citizens, members of communities or as "neighbours" in a wider sense under the new constitutional dispensation. In this context "neighbours" are regarded as people living together in close proximity as members of communities and citizens of the new constitutional democracy without necessarily residing on or using adjoining parcels of land. In particular, he explains that:

In the past, neighbour law was mostly concerned with mutual respect and tolerance between neighbours from largely similar social, cultural and economic backgrounds; in future, mutual accommodation and tolerance may have to include respect for land use related to extreme poverty and homelessness, even when such use causes annoying and possibly unlawful effects for neighbours. ${ }^{14}$

In a constitutional context characterised by its insistence upon equality, freedom and human dignity, ${ }^{15}$ neighbour law can no longer be construed in terms of notions of the rights of competing but more or less equal property

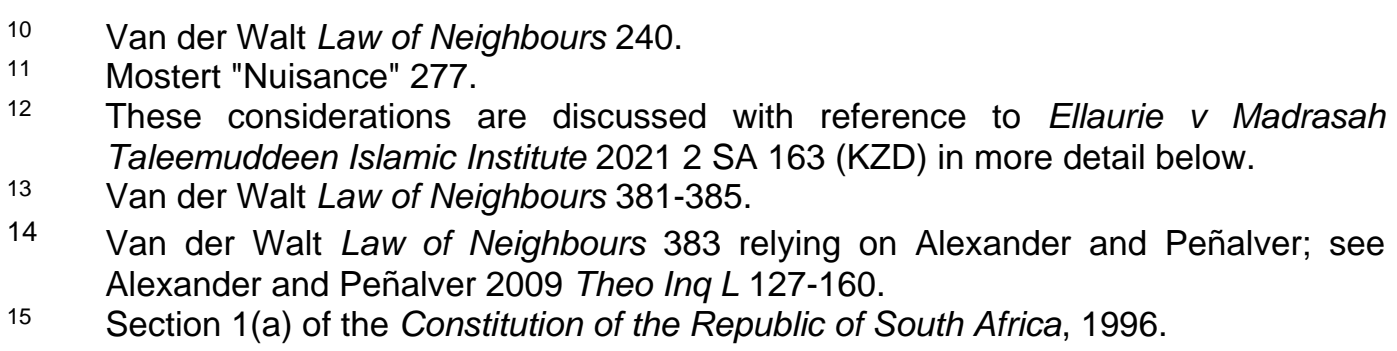


owners and property occupiers. From a constitutional perspective, the role of neighbour law should be to provide just and equitable solutions for conflicts arising from the fact that neighbours from different social, cultural, customary and religious backgrounds and with different rights and interests are living together in close proximity. To this end, broader constitutional values such as $u b u n t u^{16}$ may be infused in the common law reasonableness test $^{17}$ to assist courts in balancing competing rights and interests in a principled way to "promote the constitutional vision of a caring society based on good neighbourliness and shared concern". ${ }^{18}$ uBuntu not only places focus on one's concern for one's fellow neighbour, communitarianism and social solidarity but also encompasses many "other values such as fairness, empathy, justice, sympathy, equity and compassion". ${ }^{19}$ In this way, the principle of reasonableness, and the concept of $u b u n t u^{20}$ may inform the exercise of rights and interests in a community, as these concepts emphasise sharing, co-responsibility and "the mutual enjoyment of rights by all". ${ }^{21}$

The impact of the Covid-19 pandemic has arguably exacerbated the need to reiterate this premise. The pandemic will undoubtedly require a reconsideration of at least some principles of neighbour law, particularly the concept of "reasonableness" in the context of nuisance law. This is not particularly problematic as the parameters of nuisance law - especially in

16 There is no single definition or concept of ubuntu. In Port Elizabeth Municipality $v$ Various Occupiers 20051 SA 217 (CC) para 37 the court described the spirit of ubuntu as a "unifying motif of the Bill of Rights". See further Bennett 2011 PELJ 3031; Mokgoro 1998 PELJ 2-3; Himonga 2013 J Afr L 173.

Himonga, Taylor and Pope 2013 PELJ 371-374 referring to Keep and Midgley "Emerging Role of Ubuntu-Botho" 47-48 explain that there is a considerable overlap between the values embodied by so-called Western models of human rights and those embraced by the concept of ubuntu. Therefore, it should be apparent that ubuntu can be applied to virtually any area of law. In this respect see Bennet 2011 PELJ 30-61 in general where the author illustrates that ubuntu has been used in a series of judgments in the Constitutional and High Courts in different areas of the law (constitutional law, criminal law, administrative law, property law, family law, law of delict and law of contract). See further Kamga 2018 AHRLJ 638-646; Nkosi 2018 SAPL 12-17. of Johannesburg v Rand Properties (Pty) Ltd 20076 SA 417 (SCA) para 62; Nkosi 2018 SAPL 16; Bennet 2011 PELJ 40-42. Nkosi 2018 SAPL 17; Kamga 2018 AHRLJ 647.

20 Himonga, Taylor and Pope 2013 PELJ 370, referring to Keep and Midgley "Emerging Role of Ubuntu-Botho" 48.

$21 \quad S$ v Makwanyane 19953 SA 391 (CC) para 224 (hereafter Makwanyane); Barkhuizen v Napier 20077 BCLR 691 (CC) paras 224-225. Moreover, the court in Makwanyane para 306 described ubuntu as a "shared value and ideal that runs like a golden thread across cultural lines". See further Keep and Midgley "Emerging Role of Ubuntu-Botho" 47-48; Kamga 2018 AHRLJ 640. 
the context of reasonableness - have already shifted in the light of constitutional parameters. ${ }^{22}$ Accordingly, this article seeks to explore the notion of living closely together in mutual forbearance and tolerance in a time of a pandemic and the broad implications for cases dealing with a nuisance causing annoyance or discomfort (nuisance in the narrow sense).

The article is divided into three parts. The first part addresses the reasonableness standard as it is ordinarily applied in neighbour law. This is done by being mindful of how the standard is to be viewed in the light of the Constitution of the Republic of South Africa, 1996 (hereafter the Constitution) and the importance of taking cognisance of what it means to be a neighbour in the constitutional dispensation. In the section that follows, the reasonableness standard is situated in the context of nuisance law, with its underlying premise focussed on the so-called reasonable use of property. The following section evaluates the extent to which the notions of reasonableness and normal use have evolved in the new constitutional dispensation to provide a sufficient framework for the adjudication of nuisance law disputes during the global pandemic. This is done by critically analysing Ellaurie $v$ Madrasah Taleemuddeen Islamic Institute,,$^{23}$ a judgment decided during the pandemic. We reflect on whether the court could have reached a different outcome given the rich existing law governing what it means to be a neighbour in the light of the Constitution.

\section{2 "Living together under the Constitution": The reasonableness standard in neighbour law}

In South Africa the law of nuisance developed from and is founded on the Roman law maxim, sic utere tuo ut alienum non laedas. ${ }^{24}$ Traditionally under the common law the notion of "neighbours" concerned neighbouring owners and their mutual and reciprocal rights and obligations to use their land in a reasonable manner so as not to infringe upon a neighbouring owner's entitlements of use and enjoyment flowing from his or her ownership of the land. ${ }^{25}$ It is in this context that the common-law concept of ownership generally accepted in South Africa is found, as in Gien $v$ Gien, ${ }^{26}$ where Spoelstra AJ held that:

\footnotetext{
22 Van der Walt 2014 Journal for Law, Property and Society 15-106. See further Dhilwayo and Dyal-Chand "Property in Law" 295. 
The right of ownership is the most comprehensive real right that a person can have in respect of a thing. The point of departure is that a person can, in respect of immovable property, do with and on his property, as he pleases. This apparently unfettered freedom is, however, a half-truth. The absolute power of an owner is limited by the restrictions imposed thereupon by the law. ${ }^{27}$

Accordingly, this description of ownership as the most complete right does not suggest that ownership is absolute or that it cannot be limited. ${ }^{28}$ Rather, it is accepted that ownership has always been subject to limitations. ${ }^{29}$ Accordingly, where landowners exercise their ius utendi and it interferes with or disturbs the neighbouring landowner's similar use right, the law limits both their rights by imposing reciprocal obligations on them. ${ }^{30}$ Each landowner is obliged not to impose a heavier burden on neighbouring owners than they are themselves obliged to accept. ${ }^{31}$

Nevertheless, the notion of ownership as assigning absolute power over property, especially in so far as it relates to the ability to exclude others from using and enjoying the resource, was a widely accepted interpretation of the concept $^{32}$ and well-suited to the purposes of South Africa's apartheid government. ${ }^{33}$ In this context Van der Walt ${ }^{34}$ highlights and warns against

27 Gien 1120C-E. Steyn CJ expressed a similar view in Regal $v$ African Superslate (Pty) Ltd 19631 SA 102 (A) 106H-107B (hereafter Regal). The Constitutional Court in Van der Merwe $v$ Taylor 20081 SA 1 (CC) para 26 added a constitutional element to the concept of ownership laid down in Gien. The court described the concept of ownership as potentially conferring upon the owner the most complete or comprehensive right in or control over a thing. The court held further that: "The most comprehensive control over the property does not imply unfettered freedom to do with the thing as one pleases. However comprehensive, and although protected against arbitrary deprivation under section 25(1), ownership like any other right, is not absolute." See further Muller et al Silberberg and Schoeman's Law of Property 125-134; Van der Merwe and Pope "Property" 410; Mostert and Pope Principles of the Law of Property 345; Van der Walt Law of Neighbours 275. Mostert and Pope Principles of the Law of Property 116-157; Van der Merwe Sakereg 176-178; Muller et al Silberberg and Schoeman's Law of Property 125-134. Van der Walt and Pienaar Introduction to the Law of Property 93; Mostert and Pope Principles of the Law of Property 116-157; Van der Merwe Sakereg 176-178; Scott 2011 Acta Juridica 23; Birks 1985 Acta Juridica 1; Visser 1985 Acta Juridica 39. Gien 1121B. Gien 1121B.

Mostert 2014 PELJ 773; Van der Merwe Oorlas in die Suid-Afrikaanse Reg 12-13; Scholtens "Law of Property" 578-579.

33 Daniels v Scribante 20174 SA 341 (CC) (hereafter Daniels) paras 14-21, 90; Mostert and Pope Principles of the Law of Property 90.

$34 \quad$ Van der Walt 1999 Koers 261-264. The following cases particularly illustrate the use of neighbour law as a means of preventing the establishment of new (mostly black) residential areas in the vicinity of established (mostly white) neighbourhoods: East London Western Districts Farmers' Association $v$ Minister of Education and Development 19892 SA 63 (A); Diepsloot Residents' and Landowners' Association v Administrator Transvaal 19933 SA 49 (T); Diepsloot Residents' and Landowners' 
using neighbour law for the preservation of the "sameness" of neighbourhoods - as was essentially the case during apartheid. In the South African context, the entitlements of ownership and the ability to exercise ownership were specifically also affected by the race-based approach to land during the apartheid era. ${ }^{35}$ Despite the abolition of apartheid statutes, which formalised discriminatory, race-based land use and ownership, the legacy of dispossession remains prevalent in this democratic post-apartheid society. ${ }^{36}$ As a result, in the constitutional dispensation private ownership continues to exist but must coincide with modern-day practice, be aligned with the future needs of South African society, and endorse the prevailing constitutional and transformational demands. ${ }^{37}$

In a constitutional framework that requires the promotion and protection of human rights and is founded on fundamental values such as human dignity, equality and freedom there is a need to develop a society based on "good neighbourliness and shared concern". ${ }^{38}$ Moreover, as a broader constitutional value and legal norm ubuntu inherently embodies deep notions of inclusivity, making it an "ideal overarching vehicle for expressing shared values"39 and rendering it very well suited to spearheading the development of a genuinely plural legal culture.

In this context the Covid-19 pandemic allows us "to reflect upon and possibly adapt the ways in which we live together as citizens in the open and democratic post-apartheid society based on human dignity, freedom and equality." 40 In the light of the demands of transformation, ${ }^{41}$ the

Association v Administrator Transvaal 19943 SA 336 (A); Minister of Public Works $v$ Kyalami Ridge Environmental Association 20013 SA 1151 (CC); Joubert v Van Rensburg 20011 SA 753 (W). On these cases, described as "nuisance eviction cases", also see Van der Walt 2002 SALJ 825-833.

Pienaar "'Unlawful Occupier'" 311-314; Shoprite Checkers (Pty) Ltd v Member of the Executive Council for Economic Development, Environmental Affairs and Tourism, Eastern Cape 20156 SA 125 (CC) paras 34-36. Also see Mostert and Pope Principles of the Law of Property 90-91, 116. Van der Walt Law of Neighbours 381.

37 Badenhorst, Pienaar and Mostert Law of Property 93. First National Bank of SA Ltd t/a Wesbank v Commissioner for the South African Revenue Services; First National Bank of SA Limited t/a Wesbank v Minister of Finance 20024 SA 768 (CC) paras 49-50; Offit Enterprises v Coega Development Corporation (Pty) Ltd 20111 SA 293 (CC) para 46.

39 Himonga, Taylor and Pope 2013 PELJ 370 referring to Keep and Midgley "Emerging Role of Ubuntu-Botho" 48.

$40 \quad$ Van der Walt Law of Neighbours 381.

$41 \quad$ Van der Walt Property in the Margins 16; Daniels para 136; Nkosi 2018 SAPL 3. 
Constitutional Court in Daniels ${ }^{42}$ held that in a constitutional context "a reappraisal of our conception of the nature of ownership and property" is required. The court furthermore demonstrated the unfeasibility of the absolutist conception of ownership in the constitutional context. ${ }^{43}$ The court explained that "the traditional or common-law conception of ownership creates a hierarchy of rights with ownership at the top and lesser real and personal rights that may in circumscribed circumstances subtract from it."44 Accordingly the courts have rejected this absolutist concept of ownership in the constitutional era. ${ }^{45}$ Instead, as held in Port Elizabeth Municipality $v$ Various Occupiers, ${ }^{46}$ the Constitution:

imposes new obligations on the courts concerning rights relating to property not previously recognised by the common law ... The judicial function ... is not to establish a hierarchical arrangement between the different interests involved, privileging in an abstract and mechanical way the rights of ownership over the right not be dispossessed of a home, or vice versa. Rather it is to balance out and reconcile the opposed claims in as just a manner as possible taking account of all the interests involved and the specific factors relevant in each particular case. ${ }^{47}$ (own emphasis)

Sachs $\mathrm{J}$ further exhorted the courts to:

go beyond their normal function ... [The courts are] called upon to balance competing interests in a principled way and promote the constitutional vision of a caring society based on good neighbourliness and shared concern. The spirit of ubuntu, part of the deep cultural heritage of the majority of the population, suffuses the whole constitutional order. It combines individual rights with a communitarian philosophy. It is a unifying motif of the Bill of Rights, which is nothing if not a structured, institutionalised and operational declaration in our evolving new society of the need for human interdependence, respect and concern. ${ }^{48}$

Mostert ${ }^{49}$ explains that this judgment demonstrates that the property regime has changed and developed to embody goals of social justice. Moreover, and in line with this judgment, the "constitutional vision for property"50

42

\section{Daniels para 115(b)}

Daniels para 133.

Daniels para 134

Daniels paras 133, 135. Also see Van der Walt and Dhliwayo 2017 SALJ 34-52; Dhliwayo and Dyal-Chand "Property in Law" 295-317 in general. 20051 SA 217 (CC) (hereafter PE Municipality).

PE Municipality para 23; Van der Walt and Dhliwayo 2017 SALJ 34-52; Dhliwayo and Dyal-Chand "Property in Law" 295-317 in general. Also see Van der Walt Law of Neighbours 212.

$P E$ Municipality para 23.

PE Municipality paras 36-37.

Mostert "Nuisance" 286. Also see Van der Walt Law of Neighbours 212.

Michelman and Marais "Constitutional Vision for Property" 121-146. 
increasingly calls for a "modest systemic status"51 of property rights which will inevitably impact on the role and function that ownership plays in a particular context. ${ }^{52}$

It is against this background that Van der Walt ${ }^{53}$ clarifies that the "notion of neighbours" should be construed widely, "as far as the location of the land is concerned (contiguity), but also as far as the legal status of both the alleged perpetrator and the victim of nuisance is concerned (users who are not owners)." As far as contiguity is concerned, he explains that this means that the nuisance must involve at least two properties. However, these properties do not have to be strictly adjacent - they can also be situated in close proximity or vicinity to one another. Furthermore, with regard to the legal status of the parties involved in the dispute, it is also "clear that the nuisance could emanate from neighbouring land although it is not caused by the owner or the current occupier or user of the land, just like nuisance could affect not only the owner but also the tenant or occupier of the neighbouring land." 54 This means that nuisance actions can also be instituted by or against non-owners (normally lawful possessors), such as lessees, users or other occupiers of the land. Accordingly, Van der Walt ${ }^{55}$ refers to "neighbours" as "people living more or less closely together as members of communities, citizens of the new constitutional democracy without necessarily actually residing on or using adjoining parcels of land." It is in this context that the principle of reasonableness governing nuisance law aims to harmonise and balance out respective rights, interests and obligations and solve disputes between neighbours.

While there are many descriptions of "nuisance", 56 it seems that the common concept is that a nuisance is an action (or omission) that disturbs or interferes with the "use and enjoyment of neighbouring property in a way that exceeds what could reasonably be expected of a neighbour to tolerate. ${ }^{57}$ In this regard, the law of nuisance encapsulates "mutual and reciprocal rights and obligations of reasonable use and tolerance that

\footnotetext{
$51 \quad$ Van der Walt 2014 Journal for Law, Property and Society. Pope and Du Plessis Principles of the Law of Property 90. Van der Walt Law of Neighbours 240-244.

Van der Walt Law of Neighbours 241. Also see Milton 1969 Acta Juridica 169-178; Van der Merwe Oorlas in die Suid-Afrikaanse Reg 456-466.

Van der Walt Law of Neighbours 49.

Van der Merwe "Neighbour Law" 759; Muller et al Silberberg and Schoeman's Law of Property 125. See further Van der Merwe Oorlas in die Suid-Afrikaanse Reg 187; Church and Church "Nuisance" 115-145 para 163. 
neighbouring owners and occupiers owe one another."58 Similarly, the culture of ubuntu "places emphasis on communality and on the interdependence of the members of a community." uBuntu recognises the humanity of each person and the entitlement of all people to "unconditional respect, dignity, value and acceptance" from one's community. Inherent in this communality are the ideas of the mutual enjoyment of rights, sharing and co-responsibility. ${ }^{59} \mathrm{~A}$ notion like ubuntu could therefore be pivotal in a nuisance law enquiry to determine what would constitute the reasonable use of property, and which reciprocal duties may be owed to neighbours.

To reiterate, this reciprocity entails that neighbours must not only use their land reasonably but are also obliged to tolerate and accept reasonable inferences or "annoyances" emanating from the reasonable and lawful use of land by their neighbours and the community. ${ }^{60}$ This idea of mutuality is encapsulated in the phrases "give and take" and "live and let live". ${ }^{61}$ In sum, this foundational principle of reasonableness in the law of nuisance, underlined by the constitutional value of ubuntu, should require neighbouring owners and occupiers ${ }^{62}$ to refrain from using their property in a way that causes unnecessary or unreasonable discomfort or harm to a neighbour or the community. ${ }^{63}$

Whether a particular infringement emanating from neighbouring properties in the form of smoke, ${ }^{64}$ unpleasant smells, ${ }^{65}$ fumes, disease, ${ }^{66}$ vibrations, or

$58 \quad$ Muller General Principles of the South African Property Law 85; Milton 1969 Acta Juridica 137.

$59 \quad$ Makwanyane para 224.

$60 \quad$ Van der Walt Law of Neighbours 240; Milton 1969 Acta Juridica 150; Church and Church "Nuisance" para 164.

61 Allaclas Investments (Pty) Ltd v Milnerton Golf Club Estate (Stelzner Intervening) 20072 SA 40 (C) para 21. Also see Mostert "Nuisance" 262.

62 Van der Walt Law of Neighbours 241: It is usually said that a claimant in nuisance should have a valid legal right, entitlement of licence to be present on, occupy, use or enjoy the land.

Muller General Principles of the South African Property Law 95; Van der Merwe "Neighbour Law" 759; Muller et al Silberberg and Schoeman's Law of Property 125126; Van der Walt Law of Neighbours 237.

64 On nuisance caused by smoke, generally see Van der Merwe Sakereg 188; Church and Church "Nuisance" 115-145 para 188.

65 Van der Merwe Sakereg 188; Church and Church "Nuisance" 115-145 para 186.

$66 \quad$ Wright v Cockin 20044 SA 207 (E). Also see PGB Boerdery Beleggings (Edms) Bpk $v$ Somerville 62 (Edms) Bpk 20082 SA 428 (SCA). 
noise ${ }^{67}$ is unreasonable is an entirely contextual question. ${ }^{68}$ South African courts have adopted an objective reasonableness standard to determine whether the interference amounts to an unreasonable use of a property. ${ }^{69}$ In particular, the question is whether a reasonable or "normal man of sound and liberal tastes and habits", rather than a "perverse or finicking or overscrupulous person" would have tolerated the interference. ${ }^{70}$ To determine whether a neighbour's use is objectively reasonable, a range of contextual factors may be taken into account, including ${ }^{71}$ the locality (zoning) and use of the property in the neighbourhood in which the alleged nuisance takes place (the milieu) $;{ }^{72}$ the gravity, extent and duration of the interference; ${ }^{73}$ the personality or sensitivity and motive of the person affected; 74 the utility (the benefit) for neighbouring owners and occupiers and the community at large; the social and economic conditions and customs that prevail in the community; the practicality of preventing the alleged nuisance; and/or whether there are less restrictive means or measures available to minimise

67 On nuisance caused by noise generally, see Van der Merwe Sakereg 187-188; Church and Church "Nuisance" 115-145 para 187. There has been an array of cases dealing with nuisance caused by noise such as noise from a blacksmith's workshop in a residential area (Blacker v Carter 190519 EDC 223; Graham v Dittman and Son 1917 TPD 288 (hereafter Graham)); engineering (Van den Berg v OVS Landbou Ingenieurs (Edms) Bpk 19564 SA 391 (O); construction works (Die Vereniging van Advokate (TPA) v Moskeeplein (Edms) Bpk 19823 SA 159 (T) (hereafter Die Vereniging van Advokate); Mosekeeplein (Edms) Bpk $v$ Die Vereniging van Advokate (TPA) 19833 SA 896 (T) (hereafter Moskeeplein)); chicken farming (De Charnoy v Day Star Hatchery (Pty) Ltd 19674 SA 188 (D); dog kennels (Ferreira v Grant 1941 WLD 186); a zoo (Leith v Port Elizabeth Museum Trustees 1934 EDL 211); an apparatus installed to frighten birds away from crops (Gien); a restaurant (Nelson Mandela Metropolitan Municipality v Greyvenouw CC 20042 SA 81 (SE)); a theatre/restaurant (Laskey $v$ Showzone CC 20072 SA 48 (C) (hereafter Laskey); and continuous religious services (Prinsloo v Shaw 1938 AD 570 (hereafter Prinsloo)). Van der Walt Law of Neighbours 272.

Holland v Scott 18822 EDC 307 (hereafter Holland); Prinsloo; Die Vereniging van Advokate 167. Also see Vogel $v$ Crewe 20041 All SA 587 (T).

Prinsloo 590. See further Van der Walt Law of Neighbours 275-276.

Van der Merwe "Things" para 145; Muller et al Silberberg and Schoeman's Law of Property 126; Muller General Principles of the South African Property Law 97.

Malherbe $v$ Ceres Municipality 19514 SA 510 (A), where planting trees on the pavements was regarded as normal and customary in a small town. See further Laskey.

73 See Allaclas Investments (Pty) Ltd v Milernton Golf Club 20083 SA 134 (SCA), where a high number of stray golf balls were hit into the applicant's property repeatedly over a short period of time and Laskey v Showzone CC 20072 SA 48 (C) where the court found that the loud music emanating from a theatre was too noisy, even in the inner-city context. See further Graham v Dittmann and Son 1917 TPD 288; Gien v Gien 19792 SA 1113 (T); Die Vereniging van Advokate (TPA) v Moskeeplein (Edms) Bpk 19823 SA 159 (T); Moskeerplein (Edms) Bpk v Die Vereniging van Advokate (TPA) 19833 SA 896 (T).

See Holland 322 and Prinsloo 590. 
the neighbour's discomfort or harm. ${ }^{75}$ These are ordinarily described and understood as the general principles relating to reasonableness in the context of nuisance law. The notion of reasonableness is essentially commonplace and accepted quite easily in the determination of whether particular conduct or an omission results in nuisance. In this sense, the relationship between private individuals in the context of nuisance law is ordinarily governed by this general principle. However, in the following section, we investigate whether this notion may need to be reconsidered in the new constitutional dispensation and if the application of the principle is compatible with the Constitution.

\section{Considering reasonableness through the lens of the Constitution}

\subsection{The interplay between the common law and the Constitution}

Interestingly, Du Bois and Reid ${ }^{76}$ remark that "human rights and nuisance principles are remarkably similar". Both human rights and nuisance principles are in essence "concerned with preventing the sacrifice of one person's rights on the altar of another, seeking rather to reconcile clashing interests on the basis of reasonableness." ${ }^{\text {77 }}$ They concede, however, that it would be a mistake to equate the standard of reasonableness in a nuisance dispute with balancing the interests of parties in human rights adjudication simply because both areas of law require flexibility in the weighing up of various rights, interests and obligations. ${ }^{78}$ Referring to the analysis of $\mathrm{Du}$ Bois and Reid, Van der Walt ${ }^{79}$ warns against the danger of discounting the fundamental differences between human rights law and the common (private) law especially in the South African context, where the common (private) law played a pivotal role in the inequities of the apartheid regime and the resulting social and cultural exclusion of different communities. With this caution in mind, the section seeks to evaluate the standard of

75 See Regal, where the court found that it would be exceedingly costly and reasonably unfeasible to take the necessary steps to abate the repetition of the nuisance. See further Gien, where the court held that the noise nuisance could be mitigated by switching off the apparatus causing the noise at night. See further Laskey, where measures could be taken to insulate the neighbouring property from the noise it created in the neighbourhood.

$76 \quad$ Du Bois and Reid "Nuisance" 596-603.

77 Du Bois and Reid "Nuisance" 596-603.

$78 \quad$ Mostert "Nuisance" 271; Van der Walt Law of Neighbours 313; Du Bois and Reid "Nuisance" 597.

79 Van der Walt Law of Neighbours 315. 
reasonableness as it is applied in the context of nuisance law in the light of the Constitution.

It is argued that to the extent that the law of nuisance is incompatible with the Constitution, it may need to be developed in line with section 39(2) of the Constitution. This section requires that "[w]hen interpreting any legislation, and when developing the common law or customary law, every court, tribunal or forum must promote the spirit, purport and objects of the Bill of Rights." 80 In this regard Davis ${ }^{81}$ explains that "[s]ection 8 and the related s[ection] 39(2) of the Constitution, which may be described as the developmental sections of the Constitution, mandated a continuing audit of the entire body of South African common law to ensure that all its rules were congruent with the Constitution and, if not, were to be brought in line, not only with the express provisions of chapter 2, the Bill of Rights, but also with the 'spirit, purport and objects' of the Bill of Rights." Admittedly, the difficulty arises in establishing when it is necessary to develop the common law. Davis $^{82}$ has criticised the courts for not giving any indication of how to determine when it is necessary to do so. He shows that the problem is that there is

tension between the inherently preservative nature of the common law, with the central premise being that this body of law is changed in incremental steps, with great care being taken to avoid polycentric problems, in which the consequences of change brought about in a single case remain so unpredictable that the core value of stability is compromised, and the mandate for transformation of society and hence the legal underpinnings thereof which mandate is sourced in the constitutional text. ${ }^{83}$

He calls for an animating theory which "can guide the judiciary in its negotiation of the problem". ${ }^{84}$ Courts should, as a first step, provide an accurate reflection of the existing common-law position. A court should then determine the common-law position in the normative framework of the Constitution. Once it is determined that the existing common-law rule is

Own emphasis added to the provision. Furthermore, Nkosi 2018 SAPL 9-10 argues that the Constitution, particularly ss $7-39$, is denotative of ubuntu. It was therefore not necessary to inscribe ubuntu expressly in the Constitution. Davis "Legal Transformation and Legal Education" 173. S 8(3) of the Constitution provides as follows: "When applying a provision of the Bill of Rights to a natural or juristic person in terms of subsection (2), a court - (a) in order to give effect to a right in the Bill, must apply, or if necessary develop, the common law to the extent that legislation does not give effect to that right; and (b) may develop rules of the common law to limit the right provided that the limitation is in accordance with section 36(1)." Davis 2014 Stell LR 8-9.

83 Davis 2014 Stell $L R$ 8-9.

84 Davis 2014 Stell $L R$ 8-9. The arguments raised here in the neighbour law context is based on arguments developed in Boggenpoel 2014 Stell LR 72-98. 
inconsistent with the Constitution, this conclusion requires the development of the common law. Davis believes that courts owe it to the judicial system to plot the route for further developmental journeys. Similarly, Liebenberg has made a persuasive argument for a more active role of the judiciary in aligning the private law doctrines and rules with the new normative value system underpinned by the Constitution. Liebenberg ${ }^{85}$ asserts that until the legal culture - which is grounded in the classic liberal tradition that advocates minimal state intervention and judicial interference - is freed from this bondage and focussed on the new value system reinforced by the Constitution, there will be methodological and ideological barriers that stand in the way of the application of socio-economic rights to private law rules and doctrines. Relying on Karl Klare ${ }^{86}$ and Van der Walt, ${ }^{87}$ Liebenberg ${ }^{88}$ argues that there is a disjuncture between the legal culture that dominates South African law and the normative value system grounded in the Constitution. Arguably, in her view the only way to ensure that the ideals of the Constitution are fostered is through the adoption of a more active role by the judiciary to ensure that private law doctrines and rules are brought into line with the vision of transformative constitutionalism. ${ }^{89}$

Similarly, Mokgoro ${ }^{90}$ held that the post-apartheid order of constitutionalism requires courts to develop and interpret entrenched rights "in terms of a cohesive set of values, ideal to an open and democratic society". An allinclusive value system, or common values in South Africa, could form the basis upon which to develop a South African human rights jurisprudence. One such shared value and ideal is the value of ubuntu. ${ }^{91}$

Unfortunately, this has proven to be increasingly difficult. The extent to which courts can and should advance transformative goals or effect social change has been contested. ${ }^{92}$ Moreover, in some instances courts lack the vocabulary to fully exhaust extensive and innovative possibilities. ${ }^{93}$ Nonetheless, we argue that where there is a duty to develop the common law, it should be done in line with the Constitution. What follows in the

\footnotetext{
85 Liebenberg Socio-Economic Rights Adjudication 339-341.

$86 \quad$ Klare 1998 SAJHR 146-188.

87 Van der Walt 2006 Fundamina 1-47.

88 Liebenberg Socio-Economic Rights Adjudication 340.

89 Klare 1998 SAJHR 150.

$90 \quad$ Makwanyane para 302.

$91 \quad$ Makwanyane paras 302, 306

92 See for instance Davis 2012 PELJ 9: "[T] he judiciary, because it does not 'run the country', should not intrude into core areas of social and economic policy." Also see Rosenberg Hollow Hope ch 1.

93 Boggenpoel Property Remedies 38. See further Himonga, Taylor and Pope 2013 PELJ 374-376.
} 
section below are some reflections that could guide a court in assessing whether the application of the reasonableness test in nuisance law indeed complies with the Constitution. In this light, we question how the commonlaw test for reasonableness as applied in nuisance law should be viewed in the light of the Constitution.

\subsection{The impact of the Constitution on neighbour law}

In balancing and reconciling the rights and interests of private landowners and their neighbours, it is questionable whether the development of the common law is at all necessary in the area of nuisance law, especially given that the reasonableness test is entirely flexible and already context sensitive. ${ }^{94}$

Very often courts must adjudicate private disputes between neighbours where human rights are potentially at stake. As mentioned above, nuisance law already accepts that ownership is inherently subject to limitations. ${ }^{95}$ In this context private ownership in the constitutional context is subject to constitutional limitations. The extent to which private ownership may be limited in the context of nuisance law is furthermore determined by the objective reasonableness test, which also considers opposing rights and interests in determining whether there is reasonable use of property and whether such use must be tolerated. Normatively, the law of nuisance should be influenced by human rights mechanisms and values such as ubuntu ${ }^{96}$ to transform neighbour law more broadly by ensuring that it "embodies and represents an element of good neighbourliness and citizenship, of community that reflects the transformative intentions of the Constitution." 97 To this extent it is argued that there is no apparent need to develop or replace the reasonableness test in nuisance cases where constitutional rights come into play.

Determining how a constitutional rights paradigm may intersect with the law of nuisance potentially highlights a difficult balancing act of expectations around different lifestyles. Such a balancing act would require weighing up and reconciling property and other constitutional rights and interests of diverse and changing neighbourhoods. ${ }^{98}$ This arguably applies even more

\footnotetext{
$94 \quad$ Boggenpoel Property Remedies 314; Du Bois and Reid "Nuisance" 585.

95 Gien 1120C-E. Also see in general Van der Walt 2014 Journal for Law, Property and Society.

96 Makwanyane paras 302, 306. See further Himonga, Taylor and Pope 2013 PELJ 374-376.

97 Du Bois and Reid "Nuisance" 601-602.

$98 \quad$ Mostert "Nuisance" 272.
} 
so in a time of pandemic, when parties are restricted to the boundaries of their homes and when living in close proximity with your neighbour may cause conflicts pertaining to different lifestyles and preferences. Property rights may conflict with other fundamental human rights such as the right to equality (section 9), privacy (section 14), personal security and development (section 12), the right to exercise a profession (section 22), environment (section 24), housing (section 26), health (section 27) and religious/cultural freedom (sections 15 and 28). These constitutionally protected rights could (and arguably should) influence the understanding of the reasonableness standard in nuisance law. ${ }^{99}$ This does not mean that the exercise of human rights will in all instances amount to a reasonable use of property. In this regard, courts are tasked with the responsibility of ensuring that all considerations and factors are weighed up to establish whether the use of the property amounts to an actionable nuisance. This issue came up recently in the judgment of Ellaurie, where the KwaZulu-Natal High Court failed to apply the sound and established reasonableness principle correctly in neighbour law, which could potentially have incorporated a human rights dimension. This judgment is considered in the section below to highlight the fact that courts are arguably still finding it difficult to inculcate the Constitution in the sphere of nuisance law.

\section{The case of Ellaurie $v$ Madrasah Taleemuddeen Islamic Institute: A missed opportunity?}

The case of Ellaurie may have been a chance for the court to illustrate the principle of reasonableness in the context of competing constitutional rights as enshrined in the Constitution.

In this case the applicant requested the court to interdict the noise caused by the Call to Prayer beyond the boundaries of the respondent's property. In particular, the applicant averred that:

The Call to Prayer is a foreign sound, which invades his private space. It bears down over to him. It deprives him of the enjoyment of his property and interrupts his peace and quiet. It further disrupts his sleep, listening to music and meditation. ... [T] he Call to Prayer gives the suburb a distinctly Muslim atmosphere. It attracts those of the Islamic faith and keeps non-Muslims away. The Muslim community in the area has increased by 30 percent in the past 15 years. The dominance of one group has resulted in arrogance and domination by the dominant group [and the neighbourhood] ... was a diverse, peaceful residential suburb, but the Madrasah has turned it into a Muslim enclave. ${ }^{100}$

\footnotetext{
99 Du Bois and Reid "Nuisance" 595; Mostert "Nuisance" 271-272.

100 Ellaurie paras 6-7.
} 
As mentioned above, a range of contextual factors may be taken into account in nuisance law enquiry, including the locality (zoning) and use of the property in the neighbourhood in which the alleged nuisance takes place (the milieu); the gravity, extent and duration of the interference; the personality or sensitivity and motive of the person affected; the utility (the benefit) for neighbouring owners and occupiers and the community at large; the social and economic conditions and customs that prevail in the community; the practicality of preventing the alleged nuisance; and/or whether there are less restrictive means or measures available to minimise the neighbour's discomfort or harm to determine whether the use of a neighbouring property owner is reasonable. However, it appears that the court considered only the rights of the plaintiff without considering the opposing rights and interests of the property owners and the community as a whole in establishing whether the actions of the Madrasah truly amounted to an actionable nuisance.

Despite highlighting that the applicant is "unashamedly opposed to the Islamic faith" and that the applicant regards Islam as "a false religion that discriminates against non-Muslims as non-believers", ${ }^{101}$ the court nevertheless awarded an interdict on the basis that the religious practices, that is, the Call to Prayer, infringed the applicant's use and enjoyment of his property rights. Although the court mentioned the right to freedom of religion ${ }^{102}$ it failed to consider how this right might limit the property rights of one private landowner. ${ }^{103}$ In fact, the court noted that "the applicant must prove interference [of his ownership entitlement to use and enjoy the property] and nothing more."104 In light of this superficial application of the reasonableness test we argue that the court may have found the Madrasah's actions reasonable and refused to grant the interdict had it taken proper care in considering and weighing all the relevant contextual factors, as required under the reasonableness standard in neighbour law.

In particular, the court neglected to consider the locality or character of the neighbourhood, the social utility of the Call to Prayer for the broader community (especially during a time of pandemic, when people arguably find comfort in their religious practices) ${ }^{105}$ and whether there were less

Ellaurie para 4.

Section 15 of the Constitution.

Ellaurie paras $11-13,16$ and 18.

Ellaurie para 19.

Ellaurie para 3. For example, the Madrasah houses in its property a teaching institution for Islamic religious studies with about 340 students, with a mosque and accommodation for staff and students. 
restrictive means of mitigating the noise caused by the Call to Prayer. ${ }^{106}$ In other words, as underlined by the culture of ubuntu, ${ }^{107}$ the community may derive an interest from a particular activity, ${ }^{108}$ such as allowing practices or gatherings ${ }^{109}$ which bring a sense of solidarity and togetherness to a community, especially during the period of the Covid-pandemic, when people are restricted to the confines of their homes and neighbourhood.

Moreover, while the court stated that the applicant found the Call to Prayer "particularly offensive due to his views towards Islam",110 (a notion contradictory to the spirit of ubuntu) $)^{111}$ it failed to determine whether the applicant was not simply an over-scrupulous or oversensitive neighbour. ${ }^{112}$ Moreover, it was clear from the facts that the Madrasah had no intention of using external sound amplification in future. ${ }^{113}$ These are all commonplace factors within the ambit of the reasonableness test as outlined above. These considerations should have been weighed against the individual property rights of the applicant as well as the fact that quieter conditions might ordinarily be expected in residential areas. ${ }^{114}$ That being said, even though the properties were zoned for residential purposes the court should also have taken the ever-changing character and nature of the residential area into account. ${ }^{115}$ Other material factors which the court should have considered in this noise nuisance case were the type of noise, the degree of its persistence and the times when the noise was heard. ${ }^{116}$

106 For example, the court could have considered Garden Cities v Northpine Islamic Society 19992 SA 268 (C) (hereafter Garden Cities).

107 Makwanyane para 224.

108 Pope and Du Plessis Principles of the Law of Property 144.

109 Strict regulations issued in terms of the Disaster Management Act in response to the Covid-19 pandemic were initially put in place to regulate religious gatherings. See for example the directions issued in terms of Regulation 37(1)(a) of the Regulations issued in terms of the Disaster Management Act, 2002 (GN 609 in GG 43365 of 28 May 2020).

110 Ellaurie para 17.

111 The culture of ubuntu assumes the humanity of each person and the entitlement of all people to unconditional respect, dignity, value and acceptance from one's community. Inherent in this communality are the ideas of the mutual enjoyment of rights by all, sharing and co-responsibility. These aspects are already envisaged in the reasonableness test.

112 See for example Prinsloo.

113 Ellaurie para 15.

114 Laskey para 26.

115 Laskey paras 25-26.

$116 \quad$ Laskey para 22. 
Arguably, the court's over-simplified application of the reasonableness test could be construed as an all-or-nothing solution grounded in the exclusion model of property. ${ }^{117}$ Dyal-Chand ${ }^{118}$ explains:

[O]utcomes are [often] tagged to exclusion in the form of blanket property rules and 'keep out' signs .... Sharing as an outcome is a powerful means of addressing property inequalities, limiting harmful externalities, preserving efficiency, and harnessing the extraordinary potential of outcomes in property law.

If a system of property law is more exclusion-oriented, it will often have the effect that the system is more concerned with asking who has the stronger title, and it becomes difficult to conceive of solutions other than protecting the stronger title. Therefore, "over-reliance on the exclusion model limits our imagination in developing superior outcomes in property disputes that have the potential to protect more legitimate interests in valued resources."119 Instead, Dyal-Chand ${ }^{120}$ proposes that courts adopt a three-pronged interest-outcome approach to solve property law disputes. In terms of the interest-outcome approach, the court would first establish the legitimate interests on both sides of the dispute. Once the interests are recognised and defined, the second step would be for the court to consider the possible "outcomes that could best accommodate each party's legitimate interest". ${ }^{121}$ Only during the final step should courts consider the formal title and ownership entitlements relevant to the given dispute. ${ }^{122}$

Accordingly, if the interest-outcome approach is followed, allowing the court first to consider the interests of both parties as well as the possible outcomes (such as those mediated on a previous occasion by the South African Human Rights Commission), ${ }^{123}$ followed by the property rights of each neighbour, it may have found that the religious rights and interests of the neighbour, Islamic students and broader Islamic community weighed heavier than the property rights of one property owner. ${ }^{124}$

117 Dyal-Chand 2013 Conn L Rev 650. Also see Penner ldea of Property 68-74; Merrill 1998 Neb L Rev 730-731; Merrill 2007 Wm \& Mary L Rev 1857; Smith 2004 NYU L Rev 1728; Smith 2012 Harv L Rev 1693-1694.

118 See Dyal-Chand 2013 Conn L Rev 647.

119 Dyal-Chand 2013 Conn $L \operatorname{Rev} 655$. Dyal-Chand makes this point by looking at an example in medieval times. With writs the focus was much more on outcome and property use with relatively little attention being paid to formal title.

120 Dyal-Chand 2013 Conn L Rev 677.

121 Dyal-Chand 2013 Conn L Rev 677.

122 Dyal-Chand 2013 Conn L Rev 677.

$123 \quad$ Ellaurie para 8.

124 Ellaurie para 10. 
Very crucially, the judge also failed to consider similar, existing case law. In Garden Cities, for example, the applicants similarly sought an interdict for the nuisance created by the amplified Call to Prayer. ${ }^{125}$ This case turned on the interpretation of a contractual clause in the original sale agreement, which prohibited the use of amplified sound for the Call to Prayer. Importantly, the applicants did not object to the Call to Prayer itself in Garden Cities. Rather, the applicants objected to the extent (time and duration) of the noise created by the Call to Prayer. The court found that the contract did not prohibit or exclude the use of a Call to Prayer - "it only aimed to limit the noise in the interests of the community by restricting the Calls to Prayer to the unassisted human voice." ${ }^{126}$ Mostert $^{127}$ notes that "although, given the context of the case, the court was not expected to weigh the constitutionally protected interests of one segment of the society against another, its reasoning highlights that even conduct forming part of an activity protected by the religious freedom clause of the Constitution may be unreasonable." In this light Van der Walt ${ }^{128}$ argues that

\begin{abstract}
the protection of property rights is not a necessary requirement for the protection of these non-property rights, and that the protection of the nonproperty rights might often, in a direct conflict, enjoy some constitutional, statutory or moral privilege that gives them a presumptive edge over the protection of property rights.
\end{abstract}

In other words, this reiterates the position and obligation on courts to "balance out and reconcile" 129 conflicting rights, such as the right to property (section 25) and the right to freedom of religion (section 15) - which is incorporated within the reasonableness test. It also illustrates that other constitutional rights will not always trump a private landowner's right to property (section 36 of the Constitution). Arguably the court in Ellaurie essentially established a hierarchy of fundamental rights (which is not recognised in South Africa) by focussing on ownership (property rights), rather than recognising the possible "modest systemic status" 130 of property rights in this particular context. This would entail that in the constitutional dispensation, "the protection of the property right must inevitably be a relatively modest systemic objective, given the fact that it operates within

\author{
Garden Cities 270F. \\ Mostert "Nuisance" 277. \\ Mostert "Nuisance" 277. \\ Van der Walt 2014 Journal for Law, Property and Society 104. \\ PE Municipality para 23. \\ Van der Walt 2014 Journal for Law, Property and Society 102.
}


normatively pre-determined structural constraints that secure the democratic framework within which property rights are in fact protected."131

Having had the opportunity to weigh up different constitutional rights, the court disregarded the diversifying nature and the prevailing social conditions and customs of the neighbourhood as a whole. What is even more regrettable is that it seems that the use and enjoyment of one private landowner could override the rights and interests of the broader community - which are what the reasonableness standard generally aims to consider. Arguably, if the court in Ellaurie had applied the reasonableness test correctly or followed a more nuanced approach, such as the interestoutcome approach, it may have: (i) not granted the interdict on the basis that the applicant's lack of tolerance was unreasonable given the diversification of the neighbourhood; or (ii) granted the interdict in restrictive terms, ${ }^{132}$ allowing for the Call to Prayer at limited (and reasonable) times of the day or that no sound amplification equipment might be used. Such an outcome does not discard the question of entitlement in its entirety in the sense that the question of who has an entitlement becomes irrelevant, but views the question of entitlement within a bigger context; one that has far greater potential to recognise a broader range of legitimate interests in a property dispute than it currently does. ${ }^{133}$ The latter outcome would be based on the recognition of the social utility of the Call to Prayer for the broader community as a way of affirming the identity and cultural diversity of the neighbourhood. ${ }^{134}$ In this context, it is not necessary to develop the common-law reasonableness test, as the underlying principle of nuisance law - "give and take", "live and let live" - if appropriately applied already encapsulates the notion of balancing respective rights and interests, given the context of each case. The principle of reasonableness should therefore not necessarily be problematic if applied not in isolation but in the context of what is expected by the Constitution.

\footnotetext{
131 Van der Walt 2014 Journal for Law, Property and Society 102 referring to Singer 2014 Duke LJ 1287-1335. See also Singer 2009 Cornell L Rev 1009-1062.

132 As also proposed by the South African Human Rights Commission. See Ellaurie para 8.

133 Dyal-Chand 2013 Conn L Rev 656.

134 Coggin 2020 https://www.dailymaverick.co.za/opinionista/2020-08-31-a-verystrange-judgment-in-kzn-as-court-comes-close-to-endorsing-islamophobia/ explains: "in a pluralistic democracy such as our own, these practices are not only important to these communities, but also celebrate the diversity of the South African urban environment".
} 


\section{Conclusion}

Covid-19, with its concomitant "stay at home" catchphrase, has certainly made living together as neighbours more immediate. Considered against the background of the new constitutional dispensation, South Africans are urged to reflect upon and possibly adapt how we live together as citizens and communities in an open and democratic post-apartheid (and imminently post-pandemic) society the values of which are based on the acknowledgment of the right to human dignity, freedom and equality.

Property disputes arising out of nuisance law must be decided in the light of "the recognition of socio-economic fundamental (human) rights" and the state's obligation to progressively realise these rights. ${ }^{135}$ In this regard, we need to envision a broader context where living together as neighbours is viewed as intrinsic to transforming South African society. We argue in this article that the foundational principle of nuisance law as "give and take" and "live and let live" arguably already encapsulates the notion of balancing respective rights (constitutional or otherwise) and interests given the context of each case. In a constitutional dispensation based on human dignity, equality, and freedom this inadvertently requires courts to balance out and reconcile often opposing constitutional rights. Given the "constitutional matrix" as developed in the PE Municipality-judgment, ${ }^{136}$ determining whether the use is reasonable or not involves weighing up the rights, interests and obligations of the neighbours and the community. It is argued in this article that such a balancing act is not always performed in a principled and coherent fashion, as illustrated in the recent Ellaurie judgment. It is therefore not necessary to develop the common-law reasonableness test for nuisance law to comply with the Constitution. There are numerous ways in which the ideals of the Constitution (and even specific constitutional rights other than property) could be advanced if courts were more willing (and not held back by their conservatism) and able (equipped with the necessary vocabulary) to apply private law in line with the Constitution. It is pivotal, however, that courts should apply the reasonableness test correctly, considering all the relevant circumstances of the case, including the values (ubuntu) and ideals of the Constitution. It is arguable that if this is done, neighbour law should have a greater potential to incorporate a wider range of rights and interests so that outcomes are

\footnotetext{
135 Mostert "Nuisance" 286.

136 PE Municipality para 14.
} 
fairer and more equitable, which is, after all, the goal of reasonableness in the context of neighbour law.

\section{Bibliography}

\section{Literature}

Alexander and Peñalver 2009 Theo Inq $L$

Alexander GS and Peñalver EM "Properties of Community" 2009 Theo Inq L 127-160

Badenhorst, Pienaar and Mostert Law of Property Badenhorst PJ, Pienaar JM and Mostert H Silberberg and Schoeman's The Law of Property $5^{\text {th }}$ ed (LexisNexis Butterworths Durban 2006)

Bennet 2011 PELJ

Bennet TW "Ubuntu: An African Equity" 2011 PELJ 30-61

Birks 1985 Acta Juridica

Birks $\mathrm{P}$ "The Roman Law Concept of Dominium and the Idea of Absolute Ownership" 1985 Acta Juridica 1-37

Boggenpoel 2014 Stell LR

Boggenpoel ZT "Does Method Really Matter? Reconsidering the Role of Common-Law Remedies in the Eviction Paradigm" 2014 Stell LR 72-98

Boggenpoel Property Remedies

Boggenpoel ZT Property Remedies (Juta Cape Town 2015)

Church and Church "Nuisance"

Church $\mathrm{J}$ and Church $\mathrm{J}$ "Nuisance" in Joubert WA, Faris JA and Harms LTC (eds) The Law of South Africa vol $192^{\text {nd }}$ ed (LexisNexis Durban 2006) 115145

Davis "Legal Transformation and Legal Education"

Davis D "Legal Transformation and Legal Education: Congruence or Conflict?" in Price A and Bishop M (eds) A Transformative Justice: Essays in Honour of Pius Langa (Juta Cape Town 2015) ch 10

Davis 2014 Stell LR

Davis D "Where is the Map to Guide Common-Law Development?" 2014 Stell LR 3-14 
Davis 2012 PELJ

Davis DM "The Relationship Between the Courts and the Other Arms of Government in Promoting and Protecting Socio-Economic Rights in South Africa: What about Separation of Powers?" 2012 PELJ 1-14

Dhliwayo and Dyal-Chand "Property in Law"

Dhliwayo $\mathrm{P}$ and Dyal-Chand R "Property in Law" in Muller G et al (eds) Transformative Property Law: Festschrift in Honour of AJ van der Walt (Juta Cape Town 2018) 295-317

Du Bois and Reid "Nuisance"

Du Bois F and Reid E "Nuisance" in Zimmerman R, Visser D and Reid K Mixed Legal Systems in Comparative Perspective: Property and Obligations in Scotland and South Africa (Oxford University Press Oxford 2004) 576604

Dyal-Chand 2013 Conn L Rev

Dyal-Chand R "Sharing the Cathedral" 2013 Conn L Rev 647-723

Himonga 2013 J Afr L

Himonga C "The Right to Health in an African Cultural Context: The Role of Ubuntu in the Realization of the Right to Health with Special Reference to South Africa" 2013 J Afr L 165-195

Himonga, Taylor and Pope 2013 PELJ

Himonga C, Taylor T and Pope A "Reflections on Judicial Views of Ubuntu" 2013 PELJ 370-427

Kamga 2018 AHRLJ

Kamga SD "Cultural Values as a Source of Law: Emerging Trends of Ubuntu Jurisprudence in South Africa" 2018 AHRLJ 625-649

Keep and Midgley "Emerging Role of Ubuntu-Botho"

Keep $\mathrm{H}$ and Midgley $\mathrm{R}$ "The Emerging Role of Ubuntu-Botho in Developing a Consensual South African Legal Culture" in Bruinsma F and Nelken D (eds) Recht der Werkelijkheid (Reed Business BV Gravenhage 2007) 2956

Klare 1998 SAJHR

Klare KE "Legal Culture and Transformative Constitutionalism" 1998 SAJHR 146-188 
Liebenberg Socio-Economic Rights Adjudication

Liebenberg S Socio-Economic Rights Adjudication Under a Transformative Constitution (Juta Cape Town 2010)

Merrill $1998 \mathrm{Neb}$ L Rev

Merrill TW "Property and the Right to Exclude" 1998 Neb L Rev 730-755

Merrill 2007 Wm \& Mary L Rev

Merrill TW and Smith HE "The Morality of Property" 2007 Wm \& Mary L Rev 1849-1895

Michelman and Marais "Constitutional Vision for Property"

Michelman FI and Marais EJ "A Constitutional Vision for Property: Shoprite Checkers and Beyond" in Muller G et al (eds) Transformative Property Law (Juta Cape Town 2018) 121-146

Milton 1969 Acta Juridica

Milton JRL "The Law of Neighbours in South Africa" 1969 Acta Juridica 123269

Mokgoro 1998 PELJ

Mokgoro JY "Ubuntu and the Law in South Africa" 1998 PELJ 1-11

Mostert 2014 PELJ

Mostert $\mathrm{H}$ "Land as a 'National Asset' Under the Constitution: The System Change Envisaged by the 2011 Green Paper on Land Policy and What this Means for Property Law Under the Constitution" 2014 PELJ 760-797

Mostert "Nuisance"

Mostert H "Nuisance" in Visser D and Reid E (eds) Private Law and Human Rights: Bringing Rights Home in Scotland and South Africa (Edinburgh University Press Edinburgh 2013) 256-293

Mostert and Pope Principles of the Law of Property

Mostert $\mathrm{H}$ and Pope A The Principles of the Law of Property (Oxford University Press Oxford 2010)

Muller General Principles of the South African Property Law

Muller G (ed) General Principles of the South African Property Law (LexisNexis Durban 2019)

Muller et al Silberberg and Schoeman's Law of Property

Muller $\mathrm{G}$ et al (eds) Silberberg and Schoeman's The Law of Property $6^{\text {th }}$ ed (LexisNexis Durban 2019) 125-134 
Nkosi 2018 SAPL

Nkosi S "Ubuntu and South African Law: Its Juridical Transformative Impact" 2018 SAPL 1-20

Penner Idea of Property

Penner JE The Idea of Property in Law (Oxford University Press Oxford 1997)

Pienaar "'Unlawful Occupier'"

Pienaar JM '"Unlawful Occupier' in Perspective: History, Legislation and Case Law" in Mostert H and De Waal MJ (eds) Essays in Honour of CG van der Merwe (LexisNexis Durban 2011) 309-329

Pope and Du Plessis Principles of the Law of Property

Pope A and Du Plessis E (eds) The Principles of the Law of Property $2^{\text {nd }}$ ed (Oxford University Press Oxford 2020)

Rosenberg Hollow Hope

Rosenberg GM The Hollow Hope: Can Courts Bring About Social Change? $2^{\text {nd }}$ ed (University of Chicago Press Chicago 2008)

Scholtens "Law of Property"

Scholtens J "Law of Property" in Hahlo HR and Kahn E (eds) The Union of South Africa: The Development of Its Laws and Constitution (Stevens London 1965) 571-621

Scott 2011 Acta Juridica

Scott $\mathrm{H}$ "Absolute Ownership and Legal Pluralism in Roman Law: Two Arguments" 2011 Acta Juridica 23-34

Singer 2009 Cornell L Rev

Singer JW "Democratic Estates: Property Law in a Free and Democratic Society" 2009 Cornell L Rev 1009-1062

Singer 2014 Duke LJ

Singer JW "Property as the Law of Democracy" 2014 Duke LJ 1287-1335

Smith 2004 NYU L Rev

Smith HE "Property and Property Rules" 2004 NYU L Rev 1719-1798

Smith 2012 Harv L Rev

Smith HE "Property as the Law of Things" 2012 Harv L Rev 1691-1726 
Van der Merwe Sakereg

Van der Merwe CG Sakereg $2^{\text {nd }}$ ed (Butterworths Durban 1989)

Van der Merwe "Things"

Van der Merwe CG "Things" in Joubert WA, Faris JA and Harms LTC (eds)

The Law of South Africa vol $272^{\text {nd }}$ ed (LexisNexis Durban 2014) 3-347

Van der Merwe and Pope "Property"

Van der Merwe CG and Pope A "Property" in Du Bois F (ed) Wille's Principles of the South African Law $9^{\text {th }}$ ed (Juta Cape Town 2007) 405-665

Van der Merwe "Neighbour Law"

Van der Merwe D "Neighbour Law" in Zimmermann R and Visser D (eds) Southern Cross - Civil Law and Common Law in South Africa (Oxford University Press Clarendon 1996) ch 23

Van der Merwe Oorlas in die Suid-Afrikaanse Reg

Van der Merwe D Oorlas in die Suid-Afrikaanse Reg (LLD-thesis University of Pretoria 1982)

Van der Walt 1999 Koers

Van der Walt AJ "Property Rights and Hierarchies of Power: A Critical Evaluation of Land-Reform Policy in South Africa" 1999 Koers 261-264

Van der Walt 2002 SALJ

Van der Walt AJ "Living with New Neighbours: Landownership, Land Reform and the Property Clause" 2002 SALJ 816-840

Van der Walt 2006 Fundamina

Van der Walt AJ "Legal History, Legal Culture and Transformation in a Constitutional Democracy" 2006 Fundamina 1-47

Van der Walt 2014 Journal for Law, Property and Society

Van der Walt AJ "The Modest Systemic Status of Property Rights" 2014 Journal for Law, Property and Society 15-106

Van der Walt Law of Neighbours

Van der Walt AJ The Law of Neighbours (Juta Cape Town 2010)

Van der Walt Property in the Margins

Van der Walt AJ Property in the Margins (Hart Oxford 2009) 
Van der Walt and Dhliwayo 2017 SALJ

Van der Walt AJ and Dhliwayo P "The Notion of Absolute Ownership and Exclusive Ownership: A Doctrinal Analysis" 2017 SALJ 34-52

Van der Walt and Pienaar Introduction to the Law of Property Van der Walt AJ and Pienaar GJ Introduction to the Law of Property $7^{\text {th }}$ ed (Juta Cape Town 2016)

Visser 1985 Acta Juridica

Visser D "The Absoluteness of Ownership: The South African Common Law in Perspective" 1985 Acta Juridica 39-52

\section{Case law}

Allaclas Investments (Pty) Ltd $v$ Milnerton Golf Club Estate (Stelzner Intervening) 20072 SA 40 (C)

Allaclas Investments (Pty) Ltd v Milernton Golf Club 20083 SA 134 (SCA)

Barkhuizen v Napier 20077 BCLR 691 (CC)

Blacker v Carter 190519 EDC 223

City of Johannesburg v Rand Properties (Pty) Ltd 20076 SA 417 (SCA)

Daniels v Scribante 20174 SA 341 (CC)

De Charnoy v Day Star Hatchery (Pty) Ltd 19674 SA 188 (D)

Die Vereniging van Advokate (TPA) v Moskeeplein (Edms) Bpk 19823 SA $159(\mathrm{~T})$

Diepsloot Residents' and Landowners' Association $v$ Administrator Transvaal 19933 SA 49 (T)

Diepsloot Residents' and Landowners' Association $v$ Administrator Transvaal 19943 SA 336 (A)

East London Western Districts Farmers' Association v Minister of Education and Development 19892 SA 63 (A)

Ellaurie v Madrasah Taleemuddeen Islamic Institute 20212 SA 163 (KZD) Ferreira v Grant 1941 WLD 186 
First National Bank of SA Ltd t/a Wesbank $v$ Commissioner for the South African Revenue Services; First National Bank of SA Limited t/a Wesbank $v$ Minister of Finance 20024 SA 768 (CC)

Garden Cities v Northpine Islamic Society 19992 SA 268 (C)

Gien v Gien 19792 SA $1113(\mathrm{~T})$

Graham v Dittmann and Son 1917 TPD 288

Holland $v$ Scott 18822 EDC 307

Joubert v Van Rensburg 20011 SA 753 (W)

Laskey $v$ Showzone CC 20072 SA 48 (C)

Leith v Port Elizabeth Museum Trustees 1934 EDL 211

Malherbe $v$ Ceres Municipality 19514 SA 510 (A)

Minister of Public Works v Kyalami Ridge Environmental Association 2001 3 SA 1151 (CC)

Moskeeplein (Edms) Bpk v Die Vereniging van Advokate (TPA) 19833 SA $896(\mathrm{~T})$

Nelson Mandela Metropolitan Municipality v Greyvenouw CC 20042 SA 81 (SE)

Offit Enterprises v Coega Development Corporation (Pty) Ltd 20111 SA 293 (CC)

PGB Boerdery Beleggings (Edms) Bpk v Somerville 62 (Edms) Bpk 20082 SA 428 (SCA)

Port Elizabeth Municipality v Various Occupiers 20051 SA 217 (CC)

Prinsloo v Shaw 1938 AD 570

Regal v African Superslate (Pty) Ltd 19631 SA 102 (A)

S v Makwanyane 19953 SA 391 (CC) 
Shoprite Checkers (Pty) Ltd $v$ Member of the Executive Council for Economic Development, Environmental Affairs and Tourism, Eastern Cape 20156 SA 125 (CC)

Van den Berg v OVS Landbou Ingenieurs (Edms) Bpk 19564 SA 391 (O)

Van der Merwe v Taylor 20081 SA 1 (CC)

Vogel v Crewe 20041 All SA 587 (T)

Wright v Cockin 20044 SA 207 (E)

\section{Legislation}

Black Land Act 27 of 1913

Constitution of the Republic of South Africa, 1996

Development Trust and Land Act 18 of 1936

Disaster Management Act 57 of 2002

Group Areas Act 36 of 1966

Group Areas Act 41 of 1950

Native Trust and Land Act 18 of 1936

Natives Land Act 27 of 1913

\section{Government publications}

GN 609 in GG 43365 of 28 May 2020 (Regulations issued in terms of the Disaster Management Act, 2002)

\section{Internet sources}

Coggin 2020 https://www.dailymaverick.co.za/opinionista/2020-08-31-avery-strange-judgment-in-kzn-as-court-comes-close-to-endorsingislamophobia/

Coggin T 2020 A Very Strange Judgment in KZN as Judge Comes Close to Endorsing Islamophobia https://www.dailymaverick.co.za/opinionista/202008-31-a-very-strange-judgment-in-kzn-as-court-comes-close-to-endorsingislamophobia/ accessed 26 September 2021 
South African Government 2021 https://www.gov.za/covid19/resources/regulations-and-guidelines-coronavirus-covid-19 South African Government 2021 Regulations and Guidelines: Coronavirus https://www.gov.za/covid-19/resources/regulations-and-guidelinescoronavirus-covid-19 accessed 7 September 2021

\section{List of Abbreviations}

AHRLJ

Conn L Rev

Cornell L Rev

Duke LJ

Harv L Rev

J Afr L

Neb L Rev

J L Rev

PELJ

SAJHR

SALJ

SAPL

Stell LR

Theo Inq $L$

Wm \& Mary L Rev
African Human Rights Law Journal

Connecticut Law Review

Cornell Law Review

Duke Law Journal

Harvard Law Review

Journal of African Law

Nebraska Law Review

New York University Law Review

Potchefstroom Electronic Law Journal

South African Journal of Human Rights

South African Law Journal

Southern African Public Law

Stellenbosch Law Review

Theoretical Inquiries in Law

William and Mary Law Review 